\title{
ANTECEDENTES HISTÓRICOS DO ESTABELECIMENTO DO TRIBUNAL PENAL INTERNACIONAL
}

\author{
Cláudia Perrone-Moisés \\ Professora Doutora do Departamento de Direito \\ Internacional da Faculdade de Direito da \\ Universidade de São Paulo
}

\begin{abstract}
Resumo:
Este trabalho tem por objetivo relatar, em linhas gerais, os antecedentes do estabelecimento do Tribunal Penal Internacional de caráter permanente, criado pelo Estatuto de Roma de 1998.

Abstract:

This work is in purpose to mention, in general lines, the International Criminal Court stablishment in permanent character, created by the Rome Statute of 1998.
\end{abstract}

Unitermos: Tribunal Penal Internacional, Estatuto de Roma.

Para que possamos compreender os debates jurídicos que surgem com o estabelecimento do Tribunal Penal Internacional, torna-se necessário verificar as condições históricas que lhe determinaram a criação, o que nos leva a analisar a própria História do Direito Internacional Penal. É a partir do estabelecimento do Tribunal de Nuremberg, para julgar os grandes criminosos nazistas da Segunda Guerra Mundial, que se pode falar num Direito Internacional Penal, como regime específico e distinto de responsabilidade. Conforme aponta Celso Lafer, "a concepção de um Direito Internacional Penal que Nuremberg ensejou parte do pressuposto de que existem certas exigências fundamentais da vida na sociedade internacional e que a violação das regras relativas a tais exigências constituem crimes internacionais" 1

Mas o que é o Direito Internacional Penal, ou melhor, quais são os crimes regulados por este ramo do Direito Internacional Público? O Direito Internacional Penal, seguindo a tradição de Nuremberg, pode ser qualificado, genericamente, como um direito que protege bens supremos como a paz e a dignidade do ser humano, regulando atos que violam a ordem pública internacional por meio de infrações contra o Direito Internacional.

1. Celso Lafer. A Reconstrução dos Direitos Humanos - um diálogo com o pensamento de Hannah Arendt, São Paulo, Companhia das Letras, 1988, p.169. 
Podemos, no entanto, ir além, e subdividir os crimes regulados pclo dircito internacional penal em duas categorias: o direito internacional penal, que regula os crimes considerados pela comunidade internacional como os de maior gravidade. Nessa categoria incluem-se os crimes contra a paz (agressão), os crimes de guerra, os crimes contra a humanidade e o crime de genocídio. Tais crimes foram inseridos na competencia dos tribunais internacionais: os Tribunais de Tóquio e Nuremberg, estabelecidos no Pós-Segunda Guerra, os Tribunais para a antiga Iugoslávia e Ruanda, nos anos 90, c o Tribunal Penal Internacional de caráter permanente.

Numa segunda concepção, o Direito Internacional Penal é também um Direito Penal interestatal, pois trata de delitos contra a segurança dos Estados em dada situação: os crimes regulados seriam, por exemplo, o narcotrálico, o terrorismo e a lavagem de dinheiro. A dilerença em relação à primeira categoria reside no fato de que estes crimes estão sujeitos às jurisdições internas e não a um Tribunal Internacional.

Ocorre que, segundo a concepção contemporânea, os crimes interestatais também poderiam colocar $\mathrm{cm}$ risco a ordem pública internacional. Basta lembrar o II de setembro de 2001, marcado por atos terroristas que, por sua gravidade e extensão, podem ser equiparados a um crime contra a humanidade. Daí a idéia de que o ideal seria regulá-los conjuntamente com os considerados de maior gravidade c submelê-los lambém a um Tribunal Internacional.

Em suma, enquanto, no primeiro caso, o Direito Internacional Penal, além de proibir determinados atos, impõe uma sanção, e o processo pode ser desenvolvido por um Tribunal Internacional, no segundo o ato pode ser descrito $\mathrm{c}$ proibido pelo Direito Internacional, por meio de uma convenção internacional, mas o processo será conduzido c a sanção deverá ser imposta pelo Direito interno do Estado envolvido.

Posta a definição do conteúdo do Direito Internacional Penal, passo a centrar minha análise na cvolução histórica do estabelecimento de um Tribunal Penal Internacional de caráter permanentc.

Podemos localizar o primciro antecedente da História do Dircito Internacional Penal na positivação, no século XIX, do chamado "Direito de Guerrè" modernamente conhecido como "Direito Internacional Humanitário". 2 Tal positivação ocorreu inicialmente por intermédio das Convenções de Haia, fruto das Conferências

2. Christophe Swinarski. Introdıy'ão ao Direito Internacional Humanitário, Brasília, Comiłê Internacional da Cruz Vermelha, 1996. Do mesmo autor: A Nomma a Guerra, Porto Alegre, Sergio Antonio Fabris, 1991. 
de Paz de 1899 e 1907. Segundo essas Convenções determinou-se, como princípio fundamental, que os beligerantes não têm o dircito ilimitado quanto à escolha dos meios e métodos de prejudicar o inimigo, de forma que, os criminosos de guerra - os que violavam as leis e costumes de guerra deveriam ser julgados pelos tribunais nacionais.

Outra vertente do Direito Internacional Humanitário, também positivada no início do século XIX, é a composta por normas que visam proteger os civis no período de conflito armado e a estabelecer as condições dos militares feridos e dos prisioneiros de guerra. Também nesta vertente, quem desrespeitasse as regras, seria considerado criminoso de guerra, devendo ser julgado pelos tribunais nacionais. A positivação destas normas, cujo sucesso se deve às iniciativas da Cruz Vermelha Internacional, é iniciada cm 1864, atingindo scu apogeu com as Convenções de Genebra de 1949 e seus Protocolos de 1977.

O conjunto das normas que regulam meios e métodos utilizados nos conflitos, e das que protegem os civis, os feridos e os prisioneiros de gucra, compõem o chamado Dircito Internacional Humanitário. A partir do estabelecimento dos tribunais internacionais, Nuremberg c Tóquio, Iugoslávia c Ruanda c do Tribunal Penal Internacional, os crimes de guerra passaram a ser punidos também por instâncias internacionais.

Mas, historicamente, a primeira tentativa de estabelecimento de uma jurisdição penal internacional ocorreu com o Tratado de Versalhes, que pôs fỉm à Primeira Guerra Mundial. Com base neste tratado surge a primeira possibilidade de submeter um criminoso de guerra a um Tribunal Internacional. Ficaria determinado que o ex-imperador da Alcmanha, Guilherme II, deveria ser julgado por um tribunal internacional, cm razão de ofensas à moral internacional c à autoridade sagrada dos tratados. Guilherme II nunca foi julgado, pois a Holanda, país onde se havia refugiado, negou-se a extraditá-lo, tendo $\mathrm{cm}$ vista considerar tratar-se de crime político nãopassível, portanto, de extradição.

No período entre gucrras, deu-se a primeira discussão acerca de um projeto de Convenção para a criação de uma corte penal internacional permanente, sob os auspícios da Sociedade das Nações. Assinada em 1937, a convenção não obteve as ratificações necessárias, o que impediu mais uma vez a concretização de uma corte penal internacional.

Chegamos, desse modo, ao marco principal da História do Direito Internacional Penal: o Pós-Segunda Guerra Mundial e o estabelecimento dos Tribunais 
de Nuremberg ${ }^{3}$ e Tóquio. Os horrores da guerra, o ineditismo dos campos de concentração e os requintes de crueldade utilizados haviam predisposto a comunidade internacional a não aceitar que os crimes cometidos ficassem sem julgamento. Fundando-se nessa conviç̧ão, com base na Declaração de Moscou de 1943, firmada por Roosevelt, Churchill e Stalin, os governos aliados, antes do final da guerra, estabelecem que os criminosos de guerra cujos crimes tivessem localização geográfica definida deveriam ser julgados no país onde os crimes foram cometidos. Já quanto aos crimes sem localização geográfica precisa, cujas ações estendiam suas conseqüências por todo o continente europeu, deveriam ser julgados de acordo com o que seria posteriormente definido.

Os Governos aliados decidem, ao final da guerra, o Tribunal Internacional Militar dos Grandes Criminosos de Guerra, o conhecido Tribunal de Nuremberg. Estabelecido em 8 de agosto de 1945, o Tribunal seria formado pelos quatro países vencedores, que atuariam no interesse da comunidade internacional. O Julgamento de Nuremberg estendeu-se de 20 de novembro de 1945 a $1^{\circ}$. de outubro de 1946 . Seguindo os moldes de Nuremberg, em 19 de janeiro de 1946 seria criado o Tribunal de Tóquio para julgar e punir os criminosos de guerra do Extremo Oriente.

Em Nuremberg e Tóquio, os réus foram julgados por crimes de guerra, crimes contra a paz e crimes contra a Humanidade, estes últimos, pela primeira vez definidos em Nuremberg. Alvo de muitas críticas, tendo em vista a inexistência prévia de tipificação, uma exigência básica do Direito Penal, a concepção dos crimes contra a humanidade, conforma aponta Celso Lafer, "procurava identificar algo novo, que não tinha precedente especifico no passado. Representou o primeiro esforço de tipificar como ilícito penal o ineditismo da dominação totalitária que pelas suas características próprias - o assassinato, o extermínio, a redução à escravidão, a deportação, os atos desumanos cometidos contra a população civil e as perseguições por razões políticas, raciais e religiosas, tinha uma especificidade que transcendia os crimes contra a paz e os crimes de guerra". ${ }^{4}$

Tendo em vista as críticas formuladas às normas de Direito Internacional Penal, criadas em Nuremberg, a Assembléia Geral da ONU confirmaria, em 11 de dezembro de 1946, as definições e os princípios reconhecidos pelo Tribunal de

3. H. Donnedieu de Vabres. Le procès de Nuremberg devamt les principes modernes du droit penal international, Recueil des Cours de L'Academie International de la Haye, Paris, Sirey, 1947. Joanisval Brito Gonçalves. Tribunal de Nuremberg 1945-1946: a gênese de uma nova ordem no direito internacional, Rio de Janeiro, Renovar, 2001.

4. Celso Lafer, op. cit, p. 168 
Nuremberg e de Tóquio, por meio de seus Estatutos e sentenças, como princípios do Direito Internacional (Resoluçã̉o n. 95(I) 13/2/46), que deveriam ser posteriormente sistematizados e codificados (Resolução n. 177(II) 1947), dando início, assim, a um regime específico e distinto de responsabilidade, que passaria a ser o Direito Internacional Penal.

Em 1948, outro marco importante é a Convenção das Nações Unidas para a prevenção e repressão do crime de genocídio (Resolução n. 260 A(III) -9/12/48) Nesta convenção, encontramos a definição do crime de genocídio, utilizada em diversos documentos posteriores, como no Estatuto de Roma do Tribunal Penal Internacional. O crime de genocídio é aquele cometido com a intenção de destruir, no todo ou em parte, grupos nacionais, étnicos, culturais ou religiosos. Quanto à competência para julgar os acusados de tais crimes, a Convenção determina que serão julgados pelos Tribunais nacionais do território onde tenham sido cometidos ou por um Tribunal Internacional cuja jurisdição fosse reconhecida pelas partes. Importa notar que a idéia de um Tribunal Internacional é pela primeira vez inserida em Convenção Internacional em vigor, apesar de nunca ter existido um Tribunal criado com base exclusiva nesse documento.

Na mesma ocasião, também em 1948 (Resolução n. 260B (III) 9/12/48), a Assembléia Geral das Nações Unidas requisitaria à Comissão de Direito Internacional a elaboração de um Estatuto para uma Corte Penal Internacional, elaboração que ficaria prejudicada devido à Guerra Fria e que só seria retomada em 1989, quando foram retomadas na ONU as discussões para a negociação de uma convenção internacional acerca do tema.

As discussões em torno dos crimes da Segunda Guerra voltariam, no entanto, em 1961, no julgamento do criminoso de guerra Adolf Eichmann, responsável pela deportação de milhares de vítimas para os campos de concentração e extermínio, que encontrado na Argentina, seria levado a Israel para julgamento. Na ocasião, voltariam à cena as discussões acerca da necessidade de um tribunal penal internacional. ${ }^{5}$

No entanto, somente em 1989, por iniciativa de Trinidad e Tobago junto à Assembléia Geral da ONU, é que ocorreu a retomada dos trabalhos para a criação de um Tribunal Penal Internacional. Cabe apontar também que Trinidad e Tobago, ao propor a retomada das discussões acerca do estabelecimento de um Tribunal Penal Internacional, pretendia ver incluído o crime de narcotráfico na competência deste Tribunal, o que nos remete à questão a que fiz referência no início deste trabalho.

5. Hannah Arendt. Eichmann em Jerusalém - um relato sobre a banalidade do mal, São Paulo, Companhia das Letras, 1999. 
A dẹcada de 90 passaria a ser, assim como a fase Pós-Segunda Guerra e o chamado Direito de Nuremberg, um momento de importância fundamental para o desenvolvimento do direito internacional penal. Em 1993, seria criado, por força de Resolução do Conselho de Segurança (trata-se de Tribunal ad hoc, ou seja, para determinada missão e circunstância específica), o Tribunal Internacional Penal para a antiga Iugoslávia, a fim de julgar as pessoas acusadas de graves violações ao Direito Internacional Humanitário, crime de genocídio e contra a humanidade, cometidos naquela região a partir de 1991. Esse Tribunal continua em atuação (com sede em - Haia) e vem produzindo Jurisprudência fundamental para o Direito Internacional Penal, conforme será mencionado mais adiante. ${ }^{6}$

Em 1994, também por iniciativa do Conselho de Segurança, seria criado o Tribunal de Ruanda (Resolução n. 955 do Conselho de Segurança de 8/11/94), com sede em Arusha, na Tanzânia, com competência para julgar os crimes de genocídio e violações ao Direito Internacional Humanitário, ocorridos a partir de 1990 naquele país.

Ainda em 1994, o Projeto de Estatuto para uma Corte Permanente Internacional, elaborado pela Comissão de Direito Internacional da ONU, cujos trabalhos foram retomados a partir de 1989, foi apresentado na 49:. Assembléia Geral das Nações Unidas. A Comissão sugere então a convocação de uma conferência internacional para discussão e aprovação da Convenção. A partir de 1995, um Comitê procedeu à elaboração final do que seria a futura Convenção de Roma, negociada e aprovada em 1998, e que estabeleceu, finalmente, uma jurisdição permanente para julgar os crimes de guerra, contra a paz, contra a Humanidade e os de genocídio.

Em setembro de 1998, mesmo ano da negociação da Convenção de Roma, um marco importante para o Direito Internacional Penal foi a primeira condenação internacional pelo crime de genocídio no âmbito do Tribunal Internacional para Ruanda. Na ocasião, o ex-prefeito Ruandês, Jean-Paul Akayesu, foi considerado culpado por seu papel no massacre de quinhentas mil pessoas da etnia tutsi durante a guerra em Ruanda, em 1994.

Ainda em 1998, outra decisão importante para o Direito Internacional Penal foi a da Câmara de Lordes Britânica considerando que o general Augusto Pinochet, acusado de crimes contra a Humanidade, não gozaria de imunidade, pois os atos cometidos (tortura e o desaparecimento forçado) não se enquadram no exercício das funções de um chefe de Estado que, ao contrário, deveria proteger a integridade física

6. Jean-Paul Bazelaire e Thierry Cretin. La justice pénale internationale, Paris, PUF, 2000.

7. Jean-Paul Bazelaire e Thierry Cretin, op. cit. 
de seus cidadãos e dos estrangeiros que se encontrem em seu território. A Câmara dos Lordes decidiu a favor da possibilidade de extradição do acusado, para a Espanha, país que a solicitou, com base em lei interna que prevê sua competência para julgar crimes internacionais, praticados por espanhóis ou estrangeiros, mesmo que fora do território nacional. A pretendida extradição não se concretizou, como sabemos, por "razões humanitárias", tendo em vista as condições de saúde do ex-ditador.

A partir do estabelecimento do Tribunal Internacional para a ex-Iugoslávia, conforme já se mencionou, os procedimentos avançaram nos últimos anos para a condenação de diversos autores de crimes de guerra, contra a Humanidade e de genocídio. Em junho de 2001, Slodoban Milosevic, ex-presidente da Iugoslávia, foi entregue ao Tribunal, acusado de crimes de guerra e crimes contra a humanidade, sendo a primeira vez na História que um chefe de Estado será julgado por um Tribunal Internacional. Em agosto do mesmo ano, o general servo-bósnio Radislav Krstic foi condenado a 46 anos de prisão pelo crime de genocídio, o massacre de oito mil muçulmanos na Bósnia em 1995 (Srebrenica), o maior na Europa desde o Holocausto da Segunda Guerra.

Também no ano de 2001, foram criados, no Timor Leste (1999) e no Camboja (Khmer Vermelho-1975-1979), os chamados "Tribunais Nacionais Internacionalizados" uma experiência inédita de parceria, entre a ONU e os países envolvidos, para dotar os tribunais nacionais de condições, a fim de julgar os crimes internacionais cometidos nesses países. ${ }^{8}$

Finalmente, em 2002, entrou em vigor o Estatuto de Roma do Tribunal Penal Internacional, e as discussões acerca da punição dos crimes de guerra e contra a humanidade passaram a ser reconhecidas como um dos assuntos mais importantes para a comunidade internacional.

Os desenvolvimentos recentes têm, como vimos, uma história em comum, que se inserem na luta pela positivação do direito internacional penal, um dos ramos do direito internacional público de maior importância, já que protege bens supremos como a paz e a dignidade dos seres humanos e visa dar fim à impunidade das "atrocidades inimagináveis que chocam profundamente a consciência da humanidade", conforme nos lembra o Preâmbulo do Estatuto de Roma"

São Paulo, abril de 2003.

8. Suzannah Linton. "New approaches to international justice in Cambodja and East Timor" International Review of the Red Cross, v. 84, n. 845, mars 2002, pp. 93-119.

9. Senado Federal - Projeto de Decreto Legislativo n. 152 de 2002. Aprova o texto do Estatuto de Roma do Tribunal Internacional, aprovado em junho de 1998 e assinado pelo Brasil em fevereiro de 2000. 